\title{
JOURNAL.RU
}

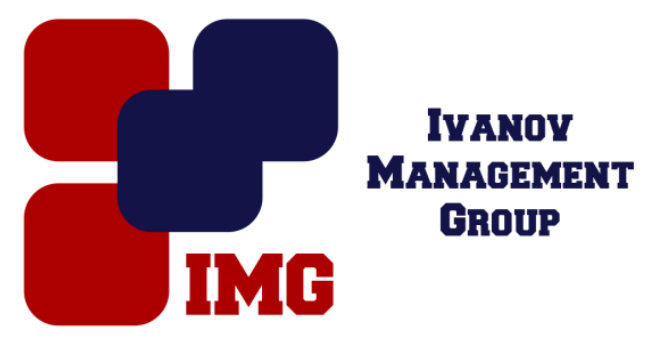

Симаходский А.С., Новикова В.П., Леонова И.А. ГБОУ ВПО «Первый Санкт-Петербургский государственный медицинский университет имени академика И.П.Павлова» Минздрава России Санкт-Петербург, Россия

doi: 10.18411/lj-31-07-2017-05

idsp 000001:1j-31-07-2017-05

\section{Особенности формирования фонда оценочных средств по дисциплине «Поликлиническая педиатрия»}

\section{Аннотация}

В статье представлен опыт формирования фонда оценочных средств для студентов 6 курса педиатрического факультета по курсу поликлинической педиатрии: тесты, ситуационные задачи, деловые игры, групповые творческие задания, индивидуальные контрольные работы, индивидуальные практические задания в симуляционном классе.

Ключевые слова: поликлиническая педиатрия, фонд оценочных средств.

Обучение в медицинском ВУЗе сегодня основано на компетентностном подходе [1]. Согласно ФГОС4 обучение студентов 6 курса на цикле поликлинической педиатрии формирует у обучающихся целый ряд общекультурных и профессиональных компетенций. В результате изучения поликлинической педиатрии студент должен знать: Основные принципы организации оказания медицинской помощи детям в поликлиниках и их структурных подразделениях; Правила ведение медицинской документации в детской поликлинике; Организацию проведения медицинской экспертизы у детей и подростков; Основные принципы оценки качества оказания медицинской помощи детям в поликлинике. Уметь: предупреждать возникновение заболеваний среди населения путем проведения профилактических и противоэпидемических мероприятий; проводить 
профилактические медицинские осмотры, диспансеризацию, диспансерное наблюдения детей; проводить сбор и медико-статистический анализ информации о показателях здоровья детей, характеризующих состояние их здоровья; диагностировить заболевания и патологические состояния у детей; неотложные состояния. Владеть: Методикой проведения экспертизы временной нетрудоспособности и иных видов медицинской экспертизы; Способами оказания первичной врачебной медико-санитарной помощи детям в амбулаторных условиях и условиях дневного стационара; Методикой оказания первичной врачебной медико-санитарной помощи детям при внезапных острых заболеваниях, состояниях, обострении хронических заболеваний, не сопровождающихся угрозой жизни пациента и не требующих экстренной медицинской помощи. Методикой оказания скорой медицинской помощи детям при состояниях, требующих срочного медицинского вмешательства; Проведением медицинской реабилитации и санаторно-курортного лечения детей; Методикой формирования у населения, пациентов и членов их семей мотивации, направленной на сохранение и укрепление своего здоровья и здоровья окружающих; Обучением детей и их родителей (законных представителей) основным гигиеническим мероприятиям оздоровительного характера, способствующим профилактике возникновения заболеваний и укреплению здоровья [2].

Фонд оценочных средств для проверки формирования знаний и умений, помимо тестов и контрольных вопросов для итогового и промежуточного контроля, включает проведение деловых игр, реализации групповых и индивидуальных творческих проектов и индивидуальной работы над рефератами на актуальные темы педиатрии.

В процессе деловой игры вырабатываются навыки проведения обследования, интерпретации клинических и лабораторных данных, постановки синдромального и этиологического диагноза, назначения лечения у детей с определенной патологией, выработка тактики этапного лечения и реабилитации, умения работать в команде, анализировать ошибки, проводить экспертную оценку качества оказания медицинской помощи детям. Деловая игра проводится в учебные часы. Ведут деловую игру в соответствии с ролями, сами студенты. Присутствуют преподаватель, который также принимает участие в выборе студентами тактики лечения. Преподаватель акцентирует внимание на клинических особенностях данного случая, причинах тактических и диагностических ошибок, направляет диагностическую мысль и принятие 
решения и оценивает работу каждого студента. В качестве группового творческого задания предлагается разработать цикл бесед для родителей по уходу и вскармливанию детей для обучения матерей в комнате здорового ребенка. Студенты по 2 человека проводят выступление по определенной теме разработанного цикла и отвечают на вопросы слушателей. При выполнении задания студентам рекомендуется пользоваться методическими разработками сотрудников кафедры [3, 4]. Оценка преподавателем основывается на правильности, полноте и доступности изложения материала. В качестве индивидуальных творческих заданий студентам предлагается оформить этапные эпикризы, выписные справки, санаторно-курортные карты и др. поликлиническую документацию на конкретных пациентов поликлиники с обязательной оценкой физического развития детей согласно существующим рекомендациям $[5,6]$. Оценка преподавателем основывается на правильности, полноте и соответствии со стандартными требованиями к оформлению документации. Другим вариантом индивидуальных творческих заданий может быть написание рефератов на актуальные темы педиатрии. Оценка рефератов проводится с учетом полноты изложения, современности использованной литературы, стиля написания. Наиболее удачные рефераты после редактирования преподавателем публикуются в сборниках, издаваемых сотрудниками кафедры $[7,8]$.

Итоговый контроль проводится в виде трехэтапного государственного экзамена. На первом этапе проводится тестовый контроль (100 тестов) и их оценка (зачет/незачет). На втором этапе проводится оценка практических навыков по непосредственному обследованию детей [9], знанию симптомов и синдромов болезни [10], диагностике и лечению непосредственно у постели больного а также методики оказания неотложной помощи в симуляционном классе [11].Третий этап- собеседование по двум ситуационным задачам, каждая из которых содержит 8-10 практических и теоретических вопросов. Сформированный кафедрой фонд оценочных средств позволяет всесторонне и в полном объеме оценить компетенции выпускника 6 курса педиатрического факультета. 
1. Романцов М.Г. Формирование профессиональных компетенций и становление компетентностного подхода при обучении в медицинском вузе/ Романцов М.Г., Храмцова Е.Г., Мельникова И.Ю.; Высшее образование сегодня: 2015.-7.-С.2-10.

2. Доскин В.А Поликлиническая педиатрия /Доскин В.А., Косенкова Т.В., Авдеева Т.Г., Шестакова В.Н., Никонорова Н.М., Федеров Г.Н., Григорьева В.Н.-М.: ГОУ ВУНМЦ МЗ РФ, 2002.- 504стр.

3. Юрьев В.В. Практика вскармливания детей первого года жизни/ Юрьев В.В., Алешина Е.И. Учебно-методическое объединение по медицинскому и фармацевтическому образованию. - СПб., 2009. - 104c.

4. Юрьев В.В. Пропедевтика детских болезней/ Юрьев В.В., Хомич М.М., Гуркина Е.Ю., Леонова И.А., Алешина Е.И. учебник для студентов учреждений высшего профессионального образования, обучающихся по специальности 060103.65 "Педиатрия" по дисциплине "Пропедевтика детских болезней". ред. Юрьев В. В., Хомича М. М. Москва,- 2012.-540с.

5. Пучкова А.Я. Оценка роста и развития ребенка/ Пучкова А.Я., Алешина Е.И., Воронович Н.Н., Симаходский А.С., Пуринь В.И., Хомич М.М., Артемова В.Б., Баирова С.В., Батанова Н.А., Болуева О.Ю., Власова Т.М., Гуркина Е.Ю., Ильина И.Я., Леонова И.А., Майорова О.Н., Пахаренко Н.В., Храмцова Е.Г. Санкт- Петербург, 2006.-36c.

6. Алешина Е.И. Методы исследования нутритивного статуса у детей и подростков: Учебное пособие/ Алешина Е.И., Андриянов А.И., Богданова Н.М., Эдлеева А.Г., Кириченко Н.Н., Комиссарова М.Ю., Леонова И.А., Новикова В.П., Хомич М.М., Юрьев В.В. Ред. В.П.Новикова и В.В.Юрьев.- СПб,-СпецЛит.,-2014,-143с.

7. Актуальные вопросы педиатрии и перинатологии / под ред. Д.О. Иванова, В.П. Новиковой, И.А. Леоновой - СПб: ИнформМед, 2015. - 328 с.

8. Знание пропедевтики - основа клинического мышления педиатра. Сборник трудов, посвященный 80-летию проф. А.Я. Пучковой/ ред.В.В.Юрьев, В.П.Новикова, А.С. Симаходский - Санкт-Петербург: ИнфорМед.-2015.-352с.

9. Алешина Е.И. Непосредственное обследование ребенка/Алешина Е.И., Воронович Н.Н., Пуринь В.И., Пучкова А.Я., Хомич М.М., Эрман М.В., Юрьев В.В.; ред.В.В.Юрьев.- Санкт-Петербург: Питер; учебное пособие.-2011 - 380с.

10. Вишневский В.И. Основные клинические симптомы и синдромы от педиатрии до гериатрии/ Вишневский В.И., Новикова В.П, Мельникова И.Ю., Хорошинина Л.П. Учебно-методическое объединение по медицинскому и фармацевтическому образованию. - СПб., 2008. - 94с.

11. Сосин С.А. Обучение специалистов в симуляционном образовательном центре СЗФМИЦ им. В.А.Алмазова» Минздрава России/Сосин С.А., Леонова И.А., Кузнецова Л.В. В сборнике Актуальные вопросы педиатрии и перинатологии / ред. Д.О. Иванов, В.П. Новикова, И.А. Леонова. СПб: ИнформМед, 2015.С 297-298. 